\title{
The Effects of Age and Number of Grafted Larvae on Some Physical Characteristics of Queen Bees and Acceptance Rate of Queen Bee Cell
}

\author{
Samet Okuyan', Ethem Akyol ${ }^{2}$ \\ ${ }^{1}$ Apiculture Research Institute, Pk:10- Dedeli - Alttnordu/Ordu, Turkey \\ ${ }^{2}$ Ayhan Şahenk Faculty of Agricultural Sciences and Technologies, Niğde Ömer Halisdemir University, 51240 Nigde, Turkey \\ A R T I C LE IN F O \\ Research Article \\ Received 06 April 2018 \\ Accepted 27 September 2018 \\ Keywords: \\ Starter hives \\ Breeding hives \\ Queen cells \\ Acceptance rate \\ Larvae \\ *Corresponding Author: \\ E-mail: sametokuyan@hotmail.com

\section{A B S T R A C T} \\ This study was carried out to determine the effects of age and number of grafted larvae on \\ acceptance rates, body weight, body length, head width and length, thorax width and \\ length, and wing width and length of queen bees. One breeding and eleven starter hives \\ were used for rearing queen bees. Totally, 495 one, two, and three-day-old larvae were \\ grafted into starter hives comprising 30, 45, and 60 and 414 larvae were accepted; thus, \\ generally, the acceptance rate was calculated as $83 \%$. The best acceptance rate was \\ calculated in three-day-old larvae group as $85.15 \%$. There were found a statistically \\ significant effect of the number of grafted larvae on body length and head width of queen. \\ However, there were any effects on weight, head length, thorax width, thorax length, \\ wing width, wing length, and acceptance rate of larvae. Age of grafted larvae did not \\ have a statistically significant effect on head width, head length, wing width and \\ acceptance rate of larvae. On the other hand, age of grafted larvae had a statistically \\ significant effect on queen weight, body length, thorax width and length, and wing length \\ of queen. If bee breeders wish to improve their stock, they should graft one-day-old \\ larvae for rearing better queen bees.
}

DOI: https://doi.org/10.24925/turjaf.v6i11.1556-1561.1955

\section{Introduction}

Queen bee is the most significant individual in the honey bee colony because only she has able to lay eggs both fertile and sterile, overlapping generations, and she also releases pheromones to prevent both workers developing new queen and developing their ovaries (Winston, 1987; Delaney et al, 2010). As a result, good quality queen bees are fundamental to successful beekeeping practices. There are some notable morphological standards of adult insects such as wet and dry weight, thorax width, head width, and wing lengths (Weaver, 1957; Fischer and Maul, 1991; Dedej et al., 1998; Hatch et al., 1999; Gilley et al., 2003; Dodologlu et al., 2004; Kahya et al., 2008), some of these have been notably correlated with queen reproductive success or fecundity (Eckert, 1934; Avetisyan, 1961; Woyke, 1971; Nelson and Gary, 1983).

In addition, Kaftanoğlu et al. (1992) suggested that the quality of queen bees is influenced by genotype, nutritional factors, rearing methods, rearing period of the year, the age of the grafted larvae, and the number of larvae that is grafted into each cell builder colony (starter colony). Grafted larvae number and grafted larvae age can be easily adjusted by beekeepers who want to rear queen bees. The optimum number of grafted larvae can allow them to rear the maximum number of good quality queen bees. If grafted larvae number is more than the optimum number, queen bee quality will go down (Korkmaz et al. 2005). In addition, Woyke (1967) indicate that the most significant element that affect queen bees' quality is the age of grafted larvae. Even though honey queen bee can be reared from up to three-day-old larvae (Mahbobi et al. 2012; Weiss, 1983; Dodologlu and Emsen 1989), the quality of queen bees is going down as the age of grafted larvae going up. According to Mahbobi et al. (2012), queen bees reared from one-day-old larvae are heavier than queen bees reared from two and three-day-old larvae, same as queen bees reared from two-day-old larvae are heavier than queen bees are reared from three-day-old larvae.

\section{Materials and Methods}

This study was carried out in Niğde province of Turkey between 19th June and 11th July. In this experiment, one breeding colony which included artificially inseminated Apis mellifera anadolica (Muğla ecotype) queen which is the indigenous honey bee genotype in central Anatolia (Adam, 1983; Güler and 
Kaftanoğlu, 1999), and eleven starter hives were used. Moreover, fresh royal jelly was used throughout larvae transfer. A digital calliper which has $0.01 \mathrm{~mm}$ sensitivity was used for measuring the length and width of wings, thorax, head and total body length. Shimadzu TW423L sensitive scale was used to measure the body weight of the queens. In addition, $\mathrm{CO}_{2}$ tanks were used to anaesthetize queen bees, which allow for an easy measurement of the physical parameters of the queens. Royal jelly spoon was used to collect royal jelly and to store it a small dark glass jar was used. A refrigerator was used to keep freshly collected royal jelly in $4{ }^{\circ} \mathrm{C}$ until it used wet grafting. 240 larvae (one, two, and three day old) were grafted into 4 different starter hives, 135 larvae (one, two, and three day old) were grafted into three different starter hives, and 120 larvae (one, two, and three day old) were grafted into four different starter hives. Thus, there are four cell starter hives comprise 60 larvae, three cell starter hives comprise 45 larvae, and four cell starter hives comprise 30 larvae. In this research, acceptance rates $(\%)$, body length $(\mathrm{mm})$, hatching weight $(\mathrm{mg})$, head length and width $(\mathrm{mm})$, thorax length and width $(\mathrm{mm})$, wing length and width $(\mathrm{mm})$ were measured. In queen rearing process, briefly, queen bee was isolated into a two frames capacity queen isolator to get exactly one, two and three-day-old larvae in the breeding hive. Throughout three days, frames in the queen isolator replaced with news daily, and all frames marked to indicate in which day it is in the isolator. Thus, 165 one day old, 165 two old's and 165 three days old larvae were grafted into plastic queen rearing cubs, and they transferred into the cell builder hives (queen less colonies) which involve high population worker bees ready to produce new queen bees (Laidlaw, 1997). Larvae were transferred into a room which well lighted, temperature of the room minimum $75^{\circ} \mathrm{F}$, and humidity was minimum $50 \%$ (Laidlaw, 1978). All accepted queen cell was transferred from cell builder hives to incubator after 10 days from grafting larvae, and all queen hatching did in the incubator. After hatching, queens were anaesthetized with $\mathrm{CO}_{2}$ immediately, and first, their body weight was measured then other parameters were measured with a digital caliper. When the larvae resting in incubator accepted larvae and unaccepted were counted, and the percentage of larvae acceptance was calculated by using formula;

RAL $=$ Accepted Larvae $/$ Total Grafted Larvae $\times 100$

RAL: The Rate of Accepted Larvae

The SPSS 13.0 for windows was used for statistical analyses. Data was given in form of arithmetical mean and \pm standard errors of mean. Differences between groups were assessed through the Anova and Duncan's multiple range test, and a chi-square test was used for the statistical analysis of cell acceptance rates.

\section{Results}

Totally, 495 larvae were grafted to rear queen bees, 414 of them were accepted and emerged as queen bees. Thus, the overall larvae acceptance rate was calculated as $83 \%$. Particularly, the acceptance rates were given Table 1 below.

In addition, queen weight, body length, head width, thorax width, thorax length, and wing length were found statistically significant, and the value of these measurements were $166.37 \mathrm{mg}, 16.47 \mathrm{~mm}, 3.84 \mathrm{~mm}, 4.42$ $\mathrm{mm}, 4.07 \mathrm{~mm}$, and $10.42 \mathrm{~mm}$ respectively. Grafted larvae age had a statistically significant effect on the weight $(166.37 \mathrm{mg})$, the body length $(16.47 \mathrm{~mm})$, thorax width $(4.42 \mathrm{~mm})$, thorax length of queen bees $(4.07 \mathrm{~mm})$, and wing length of queen bees $(10.42 \mathrm{~mm})$ of reared queens. On the other hand, age of grafted larvae did not have any statistically significant effect on head width of queen $(3.84 \mathrm{~mm})$, and wing width $(3.12 \mathrm{~mm})$. The mean values and standard errors of mean of all measurements about age of grafted larvae age were given Table 2. The effects of grafted larvae number on reared queens' physical measurements, grafted larvae number had a statistically significant effect on body length $(16.5 \mathrm{~mm})$, and head length $(3.84 \mathrm{~mm})$. However, grafted larvae number did not have a significant effect on weight (166.9 $\mathrm{mg}$ ), head length $(3.52 \mathrm{~mm})$, thorax width $(4.41 \mathrm{~mm})$, thorax length $(4.06 \mathrm{~mm})$, wing width $(3.12 \mathrm{~mm})$, and wing length $(10.45 \mathrm{~mm})$. The mean values and standard errors of mean of all measurements about grafted larvae number were given Table 3 .

Table 1 All groups larvae acceptance rates (\%)

\begin{tabular}{l|cccc}
\hline Age of Grafted Larvae & N 30* & N 45 & N 60 & Mean \\
\hline A 1** & 85.0 & 71.1 & 87.5 & 81.2 \\
A 2 & 85.0 & 86.6 & 83.7 & 85.1 \\
A 3 & 92.5 & 82.2 & 80.0 & 84.9 \\
Mean & 87.5 & 79.9 & 83.7 & 83.0 \\
\hline
\end{tabular}

${ }^{*} \mathrm{~N}$ number of grafted larvae, ${ }^{* *} \mathrm{~A}$ age of grafted larvae (day)

Table 2 Physical parameters of the queen bees depending on age of grafted larvae

\begin{tabular}{l|cccccccc}
\hline \multicolumn{1}{c|}{ AGL } & $\mathrm{W}(\mathrm{mg})$ & $\mathrm{L}(\mathrm{mm})$ & $\mathrm{HW}(\mathrm{mm})$ & $\mathrm{HL}(\mathrm{mm})$ & $\mathrm{TW}(\mathrm{mm})$ & $\mathrm{TL}(\mathrm{mm})$ & $\mathrm{WW}(\mathrm{mm})$ & $\mathrm{WL}(\mathrm{mm})$ \\
\hline One day old & $173.59 \pm 1.84$ & $16.72 \pm 0.095$ & $3.85 \pm 0.017$ & $3.52 \pm 0.019$ & $4.47 \pm 0.02$ & $4.14 \pm 0.017$ & $3.11 \pm 0.015$ & $10.55 \pm 0.031$ \\
Two day old & $166.9 \pm 1.64$ & $16.61 \pm 0.081$ & $3.83 \pm 0.019$ & $3.5 \pm 0.024$ & $4.41 \pm 0.025$ & $4.05 \pm 0.025$ & $3.14 \pm 0.012$ & $10.46 \pm 0.029$ \\
Three day old & $158.69 \pm 2.025$ & $16.07 \pm 0.105$ & $3.82 \pm 0.019$ & $3.54 \pm 0.024$ & $4.37 \pm 0.021$ & $4.02 \pm 0.023$ & $3.1 \pm 0.015$ & $10.34 \pm 0.035$ \\
General & $166.39 \pm 1.83$ & $16.46 \pm 0.42$ & $3.83 \pm 0.018$ & $3.52 \pm 0.021$ & $4.42 \pm 0.022$ & $4.07 \pm 0.022$ & $3.12 \pm 0.014$ & $10.45 \pm 0.032$ \\
\hline
\end{tabular}

AGL: Age of Grafted Larvae, W weight, L Length, HW head width, HL head length, TW thorax width, TL thorax length, WW wing width, WL wing length 
Table 3 Physical parameters of the queen bees depending on number of grafted larvae

\begin{tabular}{l|cccccccc}
\hline \multicolumn{1}{c|}{ NGL } & $\mathrm{W}(\mathrm{mg})$ & $\mathrm{L}(\mathrm{mm})$ & $\mathrm{HW}(\mathrm{mm})$ & $\mathrm{HL}(\mathrm{mm})$ & $\mathrm{TW}(\mathrm{mm})$ & $\mathrm{TL}(\mathrm{mm})$ & $\mathrm{WW}(\mathrm{mm})$ & $\mathrm{WL}(\mathrm{mm})$ \\
\hline 30 larvae & $167.63 \pm 2.23$ & $16.44 \pm 0.111$ & $3.88 \pm 0.017$ & $3.56 \pm 0.029$ & $4.43 \pm 0.023$ & $4.07 \pm 0.022$ & $3.11 \pm 0.016$ & $10.47 \pm 0.041$ \\
45 larvae & $168.92 \pm 2.088$ & $16.72 \pm 0.098$ & $3.82 \pm 0.023$ & $3.51 \pm 0.027$ & $4.41 \pm 0.032$ & $4.04 \pm 0.028$ & $3.13 \pm 0.015$ & $10.48 \pm 0.037$ \\
60 larvae & $164.23 \pm 1.586$ & $16.34 \pm 0.083$ & $3.82 \pm 0.015$ & $3.49 \pm 0.016$ & $4.41 \pm 0.017$ & $4.08 \pm 0.016$ & $3.12 \pm 0.011$ & $10.42 \pm 0.026$ \\
General & $166.93 \pm 1.96$ & $16.5 \pm 0.097$ & $3.84 \pm 0.018$ & $3.52 \pm 0.024$ & $4.42 \pm 0.024$ & $4.06 \pm 0.022$ & $3.12 \pm 0.014$ & $10.46 \pm 0.035$ \\
\hline
\end{tabular}

NGL: Number of Grafted Larvae, W weight, L Length, HW head width, HL head length, TW thorax width, TL thorax length, WW wing width, WL wing length

Table 4 Correlation coefficient (person) of the physical parameters of the queen bees

\begin{tabular}{l|cccccccc}
\hline & $\begin{array}{l}\text { Queen } \\
\text { weight }\end{array}$ & $\begin{array}{c}\text { Body } \\
\text { length }\end{array}$ & $\begin{array}{c}\text { Head } \\
\text { length }\end{array}$ & $\begin{array}{c}\text { Head } \\
\text { width }\end{array}$ & $\begin{array}{c}\text { Thorax } \\
\text { length }\end{array}$ & $\begin{array}{c}\text { Thorax } \\
\text { width }\end{array}$ & $\begin{array}{c}\text { Wing } \\
\text { length }\end{array}$ & $\begin{array}{c}\text { Wing } \\
\text { width }\end{array}$ \\
\hline $\begin{array}{l}\text { Queen } \\
\text { weight }\end{array}$ & 1 & 0.722 & 0.335 & 0.311 & 0.345 & 0.319 & 0.383 & 0.516 \\
$\begin{array}{l}\text { Body } \\
\text { length }\end{array}$ & 0.722 & 1 & 0.228 & 0.21 & 0.267 & 0.211 & 0.376 & 0.408 \\
$\begin{array}{l}\text { Head } \\
\text { length }\end{array}$ & 0.335 & 0.228 & 1 & 0.434 & 0.44 & 0.334 & 0.257 & 0.279 \\
$\begin{array}{l}\text { Head } \\
\text { width }\end{array}$ & 0.311 & 0.21 & 0.434 & 1 & 0.422 & 0.302 & 0.185 & 0.152 \\
$\begin{array}{l}\text { Thorax } \\
\text { length }\end{array}$ & 0.345 & 0.267 & 0.44 & 0.422 & 1 & 0.512 & 0.317 & 0.276 \\
$\begin{array}{l}\text { Thorax } \\
\text { width }\end{array}$ & 0.319 & 0.211 & 0.334 & 0.302 & 0.512 & 1 & 0.232 & 0.231 \\
$\begin{array}{l}\text { Wing } \\
\text { length }\end{array}$ & 0.383 & 0.376 & 0.257 & 0.185 & 0.317 & 0.232 & 1 & 0.431 \\
$\begin{array}{l}\text { Wing } \\
\text { width }\end{array}$ & 0.516 & 0.408 & 0.279 & 0.152 & 0.276 & 0.231 & 0.431 \\
\hline
\end{tabular}

Furthermore, there were statistically significant correlations between all physical characteristics of reared queen bees $(\mathrm{P}<0.01)$. The correlation coefficients are given in Table 4. The highest correlation in the physical parameters of queen bees was found between weight and body length $(\mathrm{r}=0.722 ; \mathrm{P}<0.01)$, and the lowest correlation in the physical parameters was found between wing width and head width $(\mathrm{r}=0.152 ; \mathrm{P}<0.01)$.

\section{Discussion}

The weight of queen bees might be affected by genetic factors, supplemental feeding of starter hives, age of grafted larvae, season, and bee density in starter hives (Gencer et al., 2000; Mirza, 1967; Emsen, 2004). In this study, queen weights changed between $98 \mathrm{mg}$ and 220 $\mathrm{mg}$. The average reared queen from one, two and threeday-old larvae weight was 173.59, 166.9, and 158.69 respectively. The queen weights are higher than Mahbobi et al. (2012) findings which indicate that the average of queen weights reared from one, two, and three-day-old larvae $158.83,150.94$ and $144.58 \mathrm{mg}$ respectively. However, the weight of queen was lower than findings of Akyol et al. (2008) which indicate that classified reared queens into three different group as heavy, medium and light and the average weight of these were 207.63, 193.47 , and $175 \mathrm{mg}$ respectively. The findings of these researchers illustrate that queen bee weight can have a high variability. This experiment and Akyol et al. (2008) experiment were conducted in the same place, and Apis mellifera anadolica queens were used in the breeding colony in both of these two experiments. Thus, the weight could be affected by rearing methods and the rearing season. The weight differences between Mahbobi et al. (2012) and this experiment could be attributed to the genetic and environmental basis because in this experiment Apis mellifera anadolica was used and the experiment was conducted in Turkey. On the other hand, in Mahbobi et al. (2012) experiment. Apis mellifera meda was used and that experiment was conducted in Iran. In addition, grafted larvae age significantly affected queen bee weight in this experiment just as it was the case in the experiments of (Mahbobi et al., 2012; Gencer et al., 2000). Queen bees reared from one-day-old larvae were statistically heavier than two and three-day-old larvae, and queen bees reared from two-day-old larvae were statistically heavier than three-day-old larvae. The possible reason for that is the fact that potential queen bee larvae was heavily fed with royal jelly by worker bees. One-day-old grafted larvae start heavily feeding earlier than two and three-day-old larvae. Similarly, two-day-old grafted larvae start heavily feeding earlier than three-dayold larvae. On the other hand, the number of grafted larvae did not statistically affect queen bee body weight. The possible reason of this result is that during the experiment each starter hive was fed with 1/1 sugar-water mix. Also, the experiment area was very close to a farming area, and thus bees could easily find enough pollen. Therefore, worker bees in starter hives fed grafted larvae equally. As a result, grafted larvae number could not have an effect on queen bee weight. There appears to be no previous research exploring the effects of grafted 
larvae number on queen bee weight. In addition, queen weight has a significant correlation with the physical parameters of queen bees. Body length and weight have the highest correlation $(\mathrm{r}=0.722 ; \mathrm{P}<0.01)$. and head width and weight have the lowest correlation $(\mathrm{r}=0.311 ; \mathrm{P}<0.01)$.

This research shows that the body length of queen bees is affected by both the number of grafted larvae and grafted larvae age. This is the possible effect of grafted larvae age on queen body length. The strongest correlation among the physical measurements of queen bees was between body length and queen weight. While grafted larvae number did not have an effect on queen weight, it had a significant effect on body length. The reason for this effect cannot be understood. There appears to be no previous research exploring the effects of grafted larvae age and grafted larvae number on queen bee body length. In this experiment shows that there is a strong correlation between body length and other physical measurements. In addition, Eckert (1937) indicates that there is no significant correlation between queen body length and the number of ovarioles.

The head width and head length of queen bees have a significant correlation. Grafted larvae age and grafted larvae number did not have a statistically significant effect on head length in this experiment. On the other hand, Mahbobi et al. (2012) indicated that the head length of queen bees reared from one-day-old larvae was significantly more than the head length of queen bees reared from two-day-old larvae. The possible reason has a genetic and environmental basis because in this experiment Apis mellifera anadolica was used and the experiment was conducted in Turkey, but in Mahbobi et al. (2012) experiment Apis mellifera meda was used and the experiment was conducted in Iran. There appears to be no previous research exploring the effects of grafted larvae number on queen bee head length. Moreover, in this experiment, the head width of queen bees was not affected by grafted larvae age but was affected by grafted larvae number. Tarpy et al. (2011) confirms this result. However, Mahbobi et al. (2012) showed that the head width of queen bees reared from one-day-old larvae was significantly more than the head width of queen bees reared from three-day-old larvae. The reason for this difference might be genetic and environmental because in this experiment Apis mellifera anadolica was used and the experiment was conducted in Turkey. but in Mahbobi et al. (2012) experiment Apis mellifera meda was used and the experiment was conducted in Iran. There appears to be no previous research exploring the effects of grafted larvae number on queen bee head width.

The thorax length and width of queen bees were significantly affected by the age of grafted larvae but were not affected by grafted larvae number in this experiment. There is a correlation found between thorax width and thorax length $(\mathrm{r}=0.512)$. Tarpy et al. (2011) indicated that the thorax width of queen bees reared from 0-day-old larvae was significantly more than queen bees reared from two-day-old larvae, and this experiment also confirms the results of this experiment. Although this experiment shows that the age of grafted larvae affected thorax length, Mahbobi et al. (2012) does not confirm this result. Mahbobi et al. (2012) put forward that the age of grafted larvae does not affect queen bee thorax length.
The reason of this difference might be genetic and environmental because in this experiment Apis mellifera anadolica was used and the experiment was conducted in Turkey, but in Mahbobi et al. (2012) experiment Apis mellifera meda was used and the experiment was conducted in Iran. In this study, I found that grafted larvae number does not affect thorax width and length. There appears to be no previous research exploring the effects of grafted larvae number on the thorax length and width of queen bees.

The wing width of reared queen bees was not affected by grafted larvae age in this experiment. However, Mahbobi et al. (2012) does not confirm this research and suggests that the age of grafted larvae has an effect on wing width $(\mathrm{P}<0.05)$. Moreover, there is a correlation between wing width and wing length $(r=0.431)$. The wing length of queen bees was affected by grafted larvae age. Similarly, Mahbobi et al. (2012) confirms this experiment and suggests that there are significant wing length differences between different grafted larvae ages. Wing length was not affected by grafted larvae number in this experiment $(\mathrm{P}>0.05)$. Furthermore, there appears to be no previous research exploring the effects of grafted larvae number on queen bee wing length.

The acceptance rate in this experiment was not affected by grafted larvae age $(\mathrm{P}>0.05)$. On the other hand, Hussain et al. (2007) indicates that grafted larvae age has an effect on acceptance rates, and one-day-old larvae grafted into plastic cells had a $75.53 \%$ acceptance rate in the summer season, while two-day old larvae grafted into plastic cells had a $56.66 \%$ acceptance rate. This difference might have a genetic and environmental basis. The number of grafted larvae did not affect the acceptance rate in this experiment. However, Abrol et al. (2005) does not confirm this result and indicates that more grafted larvae number has a negative effect on acceptance rates. The possible reason for this difference might be that in this experience starter colonies were fed with a syrup containing $50 \%$ sugar for the first 11 days after preparing them, but in Abrol et al. (2005) experiment starter hives were fed with a syrup containing $40 \%$ sugar just for a day. In addition, Abrol et al. (2005) experiment was conducted in India and Apis cerana was used in that study. In addition, (Koç and Karacaoğlu, 2004) showed that the acceptance rates can be affected by rearing season. Base on this fact the acceptance rate of this study could be different in a different season.

\section{Conclusion and Recommendations}

In this study, the effects of grafted larvae number and age on some physical parameters of queen bees and queen cell acceptance rate were researched. The physical parameters that were investigated were queen weight, body length, head width, head length, thorax width, thorax length, wing length, and wing width. The first step of successful queen rearing is to have a good queen cell acceptance rate. For this reason, in this study, the effects of grafted larvae age and number on queen cell acceptance rates were studied. The age of grafted larvae and the number of grafted larvae did not have a significant effect on queen cell acceptance rates in this experiment. In this experiment. starter hives were fed with 
1/1 sugar-water syrup in the first 11 days. Thus, starter hives did not have any nutritional stress, and grafted larvae could be easily fed by worker bees in starter hives. As a result of that, grafted larvae number and age did not affect the queen cell acceptance rate.

Delaney (2010) indicates that morphological sizes have a significant correlation with the fertility and reproductive success of queen bees. For this reason, in this research, the effects of the age of grafted larvae and the number of grafted larvae on the morphologic characteristics of queen bee were researched. The age of grafted larvae had a more significant effect on the morphological characteristics of queen bees than the number of grafted larvae. Grafted larvae age does not affect head width, head length, and wing width for reared queen bees in this experiment. On the other hand, the age of grafted larvae significantly affects queen weight, body length, thorax length, thorax width, and wing length for reared queen bees. This experiment shows that grafted larvae number does not affect queen weight, head length, thorax width, thorax length, wing width, and wing length for reared queen bees. On the other hand, grafted larvae number has a significant effect on the length of body and the head width of reared queen bees.

In this research, each physical parameter of reared queen bees has a significant correlation with each other. Overall, the weight of queen bees has the highest correlation with other measurements, and head width has the lowest correlation with other measurements. Furthermore, Akyol et al. (2008) indicated that the diameter of spermathecae and the number of sperm in spermathecae of heavy queen bees are more than those of light queen bees. Based on these results and information, it can be said that the most important physical parameters of queen bees are their weights. The weight of reared queen bees in this experiment was affected significantly by grafted larvae age while it was not affected by grafted larvae number. For queen rearing processes, grafting oneday-old larvae is highly recommended to rear good quality queen bees. One-day-old larvae are smaller than two and three-day-old larvae, and thus queen rearing from one-day-old larvae is more difficult than two and threeday-old larvae. However, using one-day-old larvae is significant to rear good quality queen bees. Grafted larvae number (30-60) in well-fed and strong starter hives is not really important for the quality of reared queen bees. For this reason, in queen bee rearing processes, using strong starter hives and feeding starter hives well are recommended. For future research, whether or not grafting larvae number (more than 60) has any effects on some physical parameters can be researched.

\section{References}

Abrol DP, Bhagat R, Sharma D. 2005. Mass Rearing of Apis cerana F. Queen. Journal of Asia-Pacific Entomology, 8(3): 309-317. doi:10.1016/s1226-8615(08)60251-4

Adam B. 1983. In Search of the Best Strains. Hebden Bride, UK: Northern Bee Books.

Akyol E, Yeninar H, Korkmaz A, Çakmak I. 2008. An observation study on the effects of queen age on some characteristics of honey bee colonies. Italian Journal of Animal Science, 7(1): 19-25. doi:10.4081/ijas.2008.19
Akyol E, Yeninar H, Kaftanoglu O. 2008. Live Weight of Queen Honey Bees (Apis Mellifera L.) Predicts Reproductive Characteristics. Journal of the Kansas Entomological Society, 81(2): 92-100. doi:10.2317/jkes705.13.1

Ali MA. 2012. Studies on bee venom and its medical uses. International Journal of Advancements in Research \& Technology, 69-83.

Avetisyan GA. 1961. The relation between interior and exterior characteristics of the queen and fertility and productivity of the bee colony. In: XVIII International Beekeeping Congress, pp. 44-53.

Chang CC. 2002. Estimation of total flavonoid content in propolis by two complementary colorimetric methods. Journal of food and drug analysis.

Dedej S, Hartfelder K, Aumeier P, Rosenkranz P, Engels W. 1998. Caste determination is a sequential process: Effect of larval age at grafting on ovariole number, hind leg size and cephalic volatiles in the honey bee (Apis mellifera carnica). Journal of Apicultural Research, 37(3): 183-190. doi:10.1080/00218839.1998.11100970

Delaney DA, Keller JJ, Caren JR, Tarpy DR. 2011. The physical, insemination, and reproductive quality of honey bee queens (Apis mellifera L.). Apidologie, 42(1): 1-13. doi:10.1051/apido/2010027

Dodologlu A, Emsen B, Gene F. 2004. Comparison of Some Characteristics of Queen Honey Bees (Apis melliferaL.) Reared by Using Doolittle Method and Natural Queen Cells. Journal of Applied Animal Research, 26(2): 113-115. doi:10.1080/09712119.2004.9706518

Eckert JE. 1934. Studies in the Number of Ovarioles in Queen Honeybees in Relation to Body Size. Journal of Economic Entomology, 27(3): 629-635. doi:10.1093/jee/27.3.629

Eckert JE. 1937. Relation of Size to Fecundity in Queen Honeybees. Journal of Economic Entomology, 30(4): 646648.

Emsen B. 2004. Relationship between larval age and characteristics of queen honey bees (Apis mellifera L.) after single and double grafting. In Proceeding of the 1 st European Conference of Apidologie, 66.

FAO. 2010. FAO Statistics Division Food Balance Sheets. Food and Agriculture Organization of the United Nations.

Fischer F, Maul V. 1991. Untersuchungen zu aufzuchtbedingten königinnenmerkmalen. Aninquiry into the characteristics of queens depending on queen rearing. Apidologie, 22: 444446.

Fukuda H, Ohtani T. 1977. Survival and life span of drone honeybees. Researches onPopulation Ecology, 19(1), 51-68. doi: $10.1007 / \mathrm{bf02510939}$

Fukuda H, Sek1guch1 K. 1966. Seasonal change of the honeybee worker longevity in Sapporo, North Japan, with notes on some factors affecting the life-span. Japanese Journal of Ecology, 16(5): 206-212.

Genc F. 1992. A study on determination of the effects of using different ages queens on colony performance. Proc. Ist Beekeeping Seminar East Anatolia, Erzurum, Turkey, 7795.

Vasfi Gençer H, Qasim Shah S, Firatli Ç. 2000. Effects of Supplemental Feeding of Queen Rearing Colonies and Larval Age on the Acceptance of Grafted Larvae and Queen Traits. Pakistan Journal of Biological Sciences, 3(8): 13191322. doi:10.3923/pjbs.2000.1319.1322

Gilley DC, Tarpy DR, Land BB. 2003. Effect of queen quality on interactions between workers and dueling queens in honeybee (Apis mellifera L.) colonies. Behavioral Ecology and Sociobiology, 55(2): 190-196.

Güler A. 2006. Bal Arisi. Samsun: OMU Ziraat Fakultesi Ders Kitabi (55): 9-11. 
Güler A, Kaftanoğlu O. 1999. Determination of Performances Some Important Races and Ecotypes of Turkish Honeybees (Apis mellifera L.) Under Migratory Beekeeping Conditions. Turkish Journal of Veterinary and Animal Sciences, 23(EK3): 577-582.

Harry H. Laidlaw J. 1978. Contemporary queen rearing. California, Davis: Royal Printing.

Hatch S, Tarpy DR, Fletcher D . 1999. Worker regulation of emergency queen rearing in honey bee colonies and the resultant variation in queen quality. Insectes Sociaux, 46(4): 372-377. doi:10.1007/s000400050159

Eissa IS, Hussain AE, Shehata IAA, Helaly KIM. 2007. Study of certain factors affecting queen rearing in honeybee colonies on the acceptance rate of grafted queen cells. Egypt: El-Azhar, Univ.

Kaftanoğlu O, Düzenli A, Kumova U. 1988. A study on determination of the effects of queen rearing season on queen quality under Çukurova Region conditions. Turkish Journal of Veterinary and Animal Sciences, 16(3): 567-577.

Kaftanoğlu OK. 1992. Ana arı yetiştiriciliğinin önemi ve ana arının kalitesini etkileyen faktörler. Arıcılık Semineri.

Kahya Y, Gençer HV, Woyke J. 2008. Weight at emergence of honey bee (Apis mellifera caucasica) queens and its effect on live weights at the pre and post matingperiods. Journal of Apicultural Research, 47(2): 118-125.

Koç AU, Karacaoglu M. 2004. Effects of Rearing Season on The Quality of Queen Honeybees (Apis Mellifera L.) Raised Under The Conditions of Aegean Region. Mellifera, p34-37.

Korkmaz A. 2005. Ana Ari Yetiştiriciliği. Samsun: Turkish Ministry of Agriculture.

Krell R. 1996. Value-added products from beekeeping. Food \& Agriculture Org.

Laidlaw HHPR. 1997. Queen Rearing and Bee Breeding. Cheshire: Wicwas Press.

Laidlaw HH. 1978. Contemporary Queen Rearing. California.

Laidlaw HH. 1992. Production of queens and package bees. The hive and the honey bee, 989-1042.

Levin MD. 1983. Value of bee pollination to US agriculture. American Entomologist, 29(4), 50-51.

Mahbobi A, Farshineh-Adl M, Woyke J, Abbasi S. 2012. Effects of the Age of Grafted Larvae and the Effects of Supplemental Feeding on Some Morphological Characteristics of Iranian Queen Honey Bees (Apis mellifera meda Skorikov, 1929). Journal of Apicultural Science, 56(1). doi:10.2478/v10289-012-0010-1

Mark W. 1987. The Biology of the Honey Bee. Cambridge: Harvard University Press.

Metorima F N, Costa-Maia F M, Halak A L, Parpinelli R S, Vagner De Alencar Arnaut De Toledo. 2015. Morphometric measurements of Africanized honeybee queens kept in an incubator or in queen banking. Acta Scientiarum. Animal Sciences, 37(1): 91. doi:10.4025/actascianimsci. v37i1. 24006

Mirza E, Dragan M, Sherbanescu S. 1967. Seasonal variability in the weight of emerging queens. In The 21 st International Apiculture Congress of Apimondia (pp. 269-273).

Masry SHD, El-Wahab TA, Hassona NM. 2015. Origin, Weight at Emergence of Virgin Honey Bee Queens and its Effect on Acceptance During Introduction. Academic Journal of Entomology, 8: 174-182.
Nelson DL, Gary NE. 1983. Honey Productivity of Honey Bee Apis-Mellifera Colonies in Relation to Body Weight Attractiveness and Fecundity of the Queen. Journal of Apicultrual Research, 22: 209-213.

Özturk AI. 2014. Quality concept in honey bee queen and factors affecting of the its quality. Journal of Aegean Agricultural Research Institute, 59-65

Page RE, Peng CY. 2001. Aging and development in social insects with emphasis on the honey bee, Apis mellifera L. Experimental Gerontology, 36(4-6): 695-711. doi:10.1016/s0531-5565(00)00236-9

Ribbands CR. 1953. The behaviour and social life of honeybees. Bee Research Association Limited.; London.

Richard F, Tarpy DR, Grozinger CM. 2007. Effects of Insemination Quantity on Honey Bee Queen Physiology. PLoS ONE, 2(10). doi:10.1371/journal.pone.0000980

Rothenbuhler WC. 1958. Genetics and breeding of the honey bee. Annual Review of Entomology, 3(1): 161-180.

Smith KM, Loh EH, Rostal MK, Zambrana-Torrelio CM., Mendiola L, Daszak P. 2013.

Pathogens, pests, and economics: drivers of honey bee colony decline and losses. EcoHealth, 10(4): 434-445.

Tarpy D, Page R. 2000. No Behavioral Control over Mating Frequency in Queen Honey Bees (Apis mellifera L.): Implications for the Evolution of Extreme Polyandry. The American Naturalist, 155(6), 820. doi:10.2307/3079103

Tarpy DR, Keller JJ, Caren JR, Delaney DA. 2011. Experimentally induced variation in the physical reproductive potential and mating success in honey bee queens. Insectes Sociaux, 58(4): 569-574. doi:10.1007/s00040-011-0180-z

Thorp RW. 2000. The collection of pollen by bees. Pollen and Pollination, 211-223. doi:10.1007/978-3-7091-6306-1_11

Weaver N. 1957. Effects of Larval Age on Dimorphic Differentiation of the Female Honey Bee1.Annals of the Entomological Society of America, 50(3): 283-294. doi:10.1093/aesa/50.3.283

Wen-Cheng H, Chong-Yuan Z. 1985. The relationship between the weight of the queen honey bee at various stages and the number of ovarioles, eggs laid and sealed brood produced. Honey Bee Science, 6(3): 113-116.

Wilson EO. 1971. The insect societies. University Press, Cambridge.

Winston M L, Dropkin J A, Taylor O R. 1981. Demography and life history characteristics of two honey bee races (Apis mellifera). Oecologia, 48(3): 407-413. doi:10.1007/ bf00346502

Winston ML, Taylor OR, Otis GW. 1983. Some Differences between Temperate European and Tropical African and South American Honeybees. Bee World, 64(1): 12-21. doi:10.1080/0005772x.1983.11097902

Woodward DR. 2007. Queen Bee: Biology, rearing and breeding. Telford Rural Polytechnic.

Woyke J. 1967. Rearing conditions and number of sperms reaching the queens spermatheca. In Proceedings of the XXI (s. 84). International Congress Apimondia.

Woyke J. 1971. Correlations Between the Age at Which Honeybee Brood was Grafted, Characteristics of the Resultant Queens, and Results of Insemination. Journal of Apicultural Research, 10(1): 45-55. doi:10.1080/ 00218839.1971.11099669 